J. Chosun Natural Sci.

Vol. 7, No. 2 (2014) pp. $87-91$

http://dx.doi.org/10.13160/ricns.2014.7.2.87

\title{
A Correlative Study on Amyloid $\beta$-Induced Cell Death Independent of Caspase Activation
}

\author{
Pham Thi Dieu Tuyet ${ }^{\dagger}$
}

\begin{abstract}
Amyloid beta $(A \beta)$ peptide has been implicated in the pathogenesis of Alzheimer's disease and has been reported to induce apoptotic death in cell culture. Cysteine Proteases, a family of enzymes known as caspases, mediate cell death in many models of apoptosis. In the present study, we examined the caspase activity and cell death in A $\beta$-treated SHSY5Y cells, as an attempt to elucidate the relationship between the type of caspase and A $\beta$-induced cell death. A $\beta$ at $20 \mu \mathrm{M}$ induce activation of caspase-3, 8 and 9 activity, but not the caspase-1. Caspase-3, 8 and 9 were processed by Ab treatment, consistent with the activity assay. Inhibition of the caspase activities by the selective inhibitors, however, marginally affected the cell death induced by $A \beta$. Taken together, the results indicate that $A \beta$-induced cell death may be independent of caspase activity and rather, the enzymes might be activated as a result of the cell death.
\end{abstract}

Key words: $A \beta$, Caspase, Cytotoxicity, Alzheimer's Disease

\section{Introduction}

Alzheimer's disease (AD), a progressive neurodegenerative disorder, characterized by the development of neurofibrillary tangles and the deposition of senile plaques composed mainly of aggregated (fibrillar) amyloid $\beta$ protein $(A \beta)$ in the brain $^{[1]}$. Numerous studies have demonstrated that $\mathrm{Ab}$ may have a primary role in the neuronal loss ${ }^{[1-4]}$. Application of $A \beta$ to cultured neurons induces cell death that has the characteristic features of apoptosis, such as nuclear condensation and fragmentation as well as membrane blebbing ${ }^{[2-4]}$.

The activation of certain cysteine proteases, known as caspases, is the key feature in apoptosis ${ }^{[5]}$. Inductions of apoptosis by activating several caspase family members have been reported in the $\mathrm{AD}$ brain $^{[6-7]}$. Despite the growing evidence that apoptosis takes part in neurodegenerative processes, it is still unclear whether the onset of symptoms and pathological manifestations are due to neuronal loss dependent on the caspase execution mechanism $^{[8]}$. Several studies demonstrated that in vitro

Department of Biotechnology, Hanoi University of Science and Technology, University of Hanoi, Vietnam

†Corresponding author: phamtuyet0585@gmail.com (Received : June 2, 2014, Revised : June 13, 2014 Accepted : June 25, 2014) blocking of postmitochondrial events, i.e. caspase activation, prevent the morphologic features of apoptosis but may or may not prevent cell death ${ }^{[9,10]}$. On the other hand, caspase inhibition does not prevent cell death induced by radiation in hippocampal neurons ${ }^{[11]}$, by DNA damage in cortical neurons ${ }^{[12]}$, or by $A \beta$ toxicity in telencephalic neurons ${ }^{[13]}$. In the most previous investigations, however, one or two types of caspase substrates or inhibitors were employed to probe whether the characteristic caspase was involved in the cell death. Here we investigated caspase activation using 4 types of caspase substrates upon $A \beta$ treatment and examined the cell death in the presence of 5 types of caspase inhibitors to clarify the relationship of $A \beta$ toxicity and caspase-dependent apoptosis. The results indicate that caspase could be activated by $\mathrm{A} \beta$ treatment, but all caspase inhibitors employed here invariably failed to prevent the cell death, suggesting caspase activation may not be the main cause of the cell death.

\section{Experimental Section}

\author{
2.1. Reagents \\ Ac-DEVD-AMC, Ac-YVAD-AMC, Ac-IETD-AMC, \\ Ac-LEHD-AMC, Z-DEVD-FMK, YVAD-CHO, Z- \\ IETD-FMK, Z-LEHD-FMK were purchased from
}


Alexis Biochemicals (Laufelfingen, Switzerland). Polyclonal antibodies to Caspase-3, -9 and -8 were purchased from Santa Cruz Biotechnology (Santa Cruz, CA, USA). All other chemicals were purchased from Sigma (St Louis, MO, USA).

\subsection{Preparation of $A \beta$}

Recombinant $A \beta 42$, a 42 amino-acid $A \beta$, was prepared by the same method described earlier ${ }^{[14]}$. Purified A $\beta 42$ peptides were solubilized in $100 \% 1,1,1,3,3,3-$ hexafluoro-2-propanol(HFIP), dried under a flow of nitrogen and further dried in vaccum for $30 \mathrm{~min}$. Samples were stored at $-20^{\circ} \mathrm{C}$ until use. For toxicity experiments, the peptide was dissolved in $0.1 \% \mathrm{NH}_{4} \mathrm{OH}$ at a concentration of $2 \mathrm{mg} / \mathrm{ml}$ followed by bath sonication for $10 \mathrm{~min}$. The peptide solution was then diluted with media for desired concentrations.

\subsection{Cell Culture and Cell Death Assay}

Human neuroblastoma SHSY5Y cells were cultured in F-12 Dulbecco's Modified Eagle's Medium with $10 \%$ heat-inactivated Fetal bovine serum, $1 \%$ antibiotics at $37^{\circ} \mathrm{C}$ under $5 \% \mathrm{CO}_{2}$. For the cytotoxicity assay cells were plated at a density of 20,000 cells/well in 96well plates and cultured for $24 \mathrm{~h}$ followed by serum deprivation for another $12 \mathrm{~h}$. Cells were exposed to the $\mathrm{A} \beta$ preparation and various caspase inhibitors for $24 \mathrm{~h}$ and the viability was assessed by MTT reduction test at $570 \mathrm{~nm}$ on Spectra Max (Molecular Devices, CA, USA).

\subsection{Caspase Activity Assay}

For caspase activity assay, $A \beta$ treated cells were washed with ice-cold PBS. Then $40 \mu \mathrm{L}$ of cell lysis buffer [20 mM Hepes-NaOH (pH 7.0), 1 mM EDTA, $1 \mathrm{mM}$ EGTA, $20 \mathrm{mM} \mathrm{NaCl}, 0.25 \%$ Triton X-100, 1 $\mathrm{mM}$ DTT, $1 \mathrm{mM}$ PMSF, $10 \mu \mathrm{g} / \mathrm{mL}$ leupeptin, $5 \mu \mathrm{g} / \mathrm{mL}$ pepstatin A, $2 \mu \mathrm{g} / \mathrm{mL}$ aprotinin, $25 \mu \mathrm{g} / \mathrm{mL}$ ALLN] was added into each well and incubated on ice for $20 \mathrm{~min}$. Cells were disrupted by pipetting. $50 \mu \mathrm{L}$ of $2 \mathrm{X}$ caspase assay buffer [40 mM Hepes- $\mathrm{NaOH}(\mathrm{pH} 7.0), 2 \mathrm{mM}$ EDTA, $2 \mathrm{mM}$ EGTA, $40 \mathrm{mM} \mathrm{NaCl}, 3 \mathrm{mM} \mathrm{MgCl}_{2}$, $20 \mathrm{mM}$ DTT] was added in each well. Finally $10 \mu \mathrm{L}$ different caspase subtracts were added and the release of AMC was monitored for $2 \mathrm{~h}$ in 2 min interval with excitation at $360 \mathrm{~nm}$ and emission at $480 \mathrm{~nm}$ using a microplate spectrofluorometer (Molecular Devices,
CA, USA).

\subsection{Western Blot Analysis}

Cells were harvested, washed with ice-cold PBS and resuspended in buffer consisting of $50 \mathrm{mM}$ Tris- $\mathrm{HCl}$, pH 8, $150 \mathrm{mM} \mathrm{NaCl}, 1 \%$ Triton X-100, 5 mM EGTA, $5 \mathrm{mM}$ EDTA, $1 \mathrm{mM}$ PMSF, $10 \mu \mathrm{g} / \mathrm{mL}$ leupeptin, $2 \mu \mathrm{g} /$ $\mathrm{mL}$ pepstatin $\mathrm{A}, 2 \mu \mathrm{g} / \mathrm{mL}$ aprotinin for $20 \mathrm{~min}$ on ice. The extract was obtained by centrifugation at 14,000 r.p.m. at $4^{\circ} \mathrm{C}$ for $15 \mathrm{~min}$. The amount of protein was measured through Bradford Assay. Equal amounts of protein were separated on $12 \%$ SDS-PAGE and transferred onto a PVDF membrane. The membrane was immunoprobed with primary antibodies followed by HRP conjugated secondary antibodies. The blots were visualized using WEST-ZOL (Intron Biotech, Kyungkido, Korea) reagent.

\section{Results and Discussion}

\subsection{A $\beta$ Induces Caspase-3, 8, 9 Activation, not} Caspase-1

$\mathrm{A} \beta$ has been shown to induce apoptosis in neuronal cell cultures ${ }^{[2,15]}$. To determine the functional relevance of $A \beta$ toxicity and caspase activation, SHSY5Y cells were treated with $20 \mu \mathrm{M} \mathrm{A} \beta 42$ for $24 \mathrm{~h}$. Caspases are classified into two major groups of initiators $(-1,-2,-8$, $-9,-10)$ and executioners $(-3,-6,-7)^{[16]}$. Caspase- $1,-3$, -8 , and -9 were chosen in the current study and activity of each caspase was examined using relatively selective fluorogenic substrates: YVAD-AMC for caspase-1, AcDEVD-AMC for -3, Ac-IETD-AMC for -8 and AcLEHD-AMC for -9 .

Upon treatment of $A \beta 42$, caspase- 3 was activated $2 \sim 3$ time as compared to the control (Fig. 1A). Caspase8 and -9 also appear to be activated significantly, but no significant increase for caspase- 1 activity was observed (Fig. 1A). The processing was determined for the activated caspases by western blot analysis. The immunoblot analysis show activation of caspase- $3,-8$ and -9 in cells treated with 10,20 and $40 \mu \mathrm{M} \mathrm{A} \beta 42$, although $5 \mu \mathrm{M}$ of $\mathrm{A} \beta 42$ did not show any significant processing of caspases (Fig. 1B). This results supported the caspase activities shown in Fig. 1A, indicating the activation of caspases in SHSY5Y cells treated by a certain dose of $\mathrm{A} \beta$. 
A

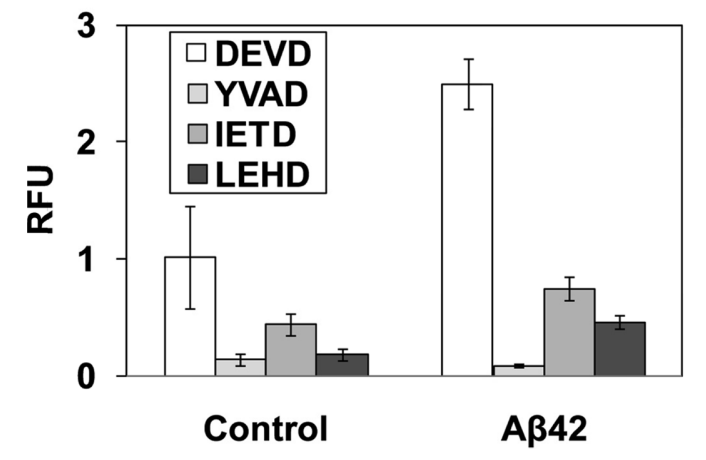

B

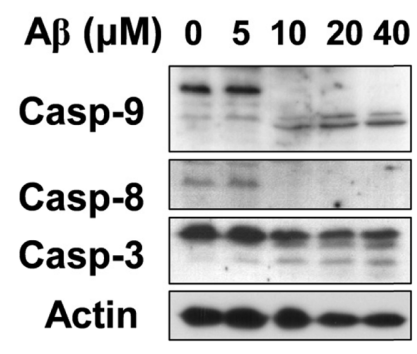

Fig. 1. Caspase activity and processing in A $\beta$-treated SHSY5Y cells. A. Activation of caspases-1, $-3,-8$ and -9 in cells treated with A $\beta 42$. SHSY5Y cells were treated with $20 \mu \mathrm{M}$ A $\beta$ for $24 \mathrm{~h}$ and caspase activity was measured using selective fluorogenic substrates as detailed in Materials and methods and Results. Bar graphs represent the averages of three independent experiments plus standard deviations. RFU indicates relative fluorescence units. B. Western blot analysis of lysates from cells treated with $A \beta 42$ for 24h. Lane1: control cells without $A \beta 42$ treatment, Lane 2: cells treated with $5 \mu \mathrm{M} A \beta$ shows no significant processing of Caspase 3, 8 and 9. Lane 3, $4 \& 5$ : cells treated with $10,20 \& 40 \mu \mathrm{M} \mathrm{A} \beta$, respectively, shows the processing of Caspase 3,8 and 9 .
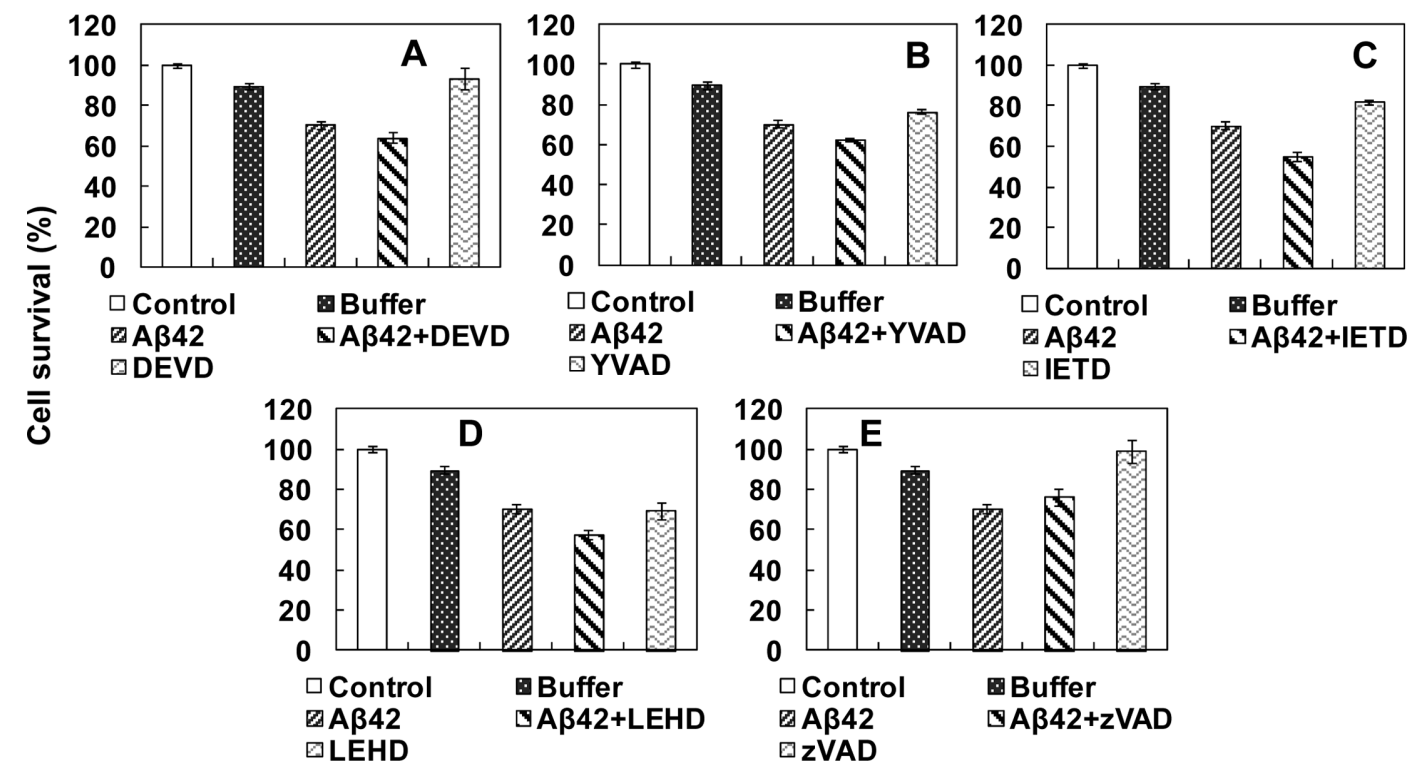

Fig. 2. Effect of caspase inhibitors on A $\beta$-induced cell death. SHSY5Y cells were treated with $A \beta 42(20 \mu \mathrm{M})$ in the absence or presence of specific inhibitors for caspase-3 (A), -1 (B), -8 (C), and -9 (D) and pan-caspase inhibitor (E) at $20 \mu \mathrm{M}$ concentration for $24 \mathrm{~h}$. MTT assay was performed to determine cell viability, as described in Materials and methods. Error bars indicate \pm standard deviation of triplicate independent experiments.

\subsection{Caspase Inhibition Does not Prevent A $\beta$ -} Induced Cell Death

To investigate the correlation of $A \beta$ toxicity and caspase activation reported in the present study, SHSY $5 Y$ cells were treated for $24 \mathrm{~h}$ with $20 \mu \mathrm{M} \mathrm{A} \beta 42$ in the presence of $20 \mu \mathrm{M}$ of selective caspase inhibitors for caspase-1 (YVAD-FMK), caspase-3 (z-DEVD-FMK), caspase-8 (Z-IETD-FMK), caspase-9 (z-LEHD-FMK) and pan-caspase inhibitor, $z$-VAD-FMK. Then, cell viability was determined using MTT assay.

$\mathrm{A} \beta 42$ at $20 \mu \mathrm{M}$ induced $30 \sim 40 \%$ reduction of cell survival (Fig. 2A). Inclusion of $20 \mu \mathrm{M}$ of caspase-3 
inhibitor (z-DEVD-FMK), unexpectedly, did not reduce the cell death (Fig. 2A). Thus, we conclude the activation of caspase-3 as shown in Fig. 1A may not be related to the cell death observed. The activation of caspase- 3 and its relationship to $A \beta 42$ toxicity remain to be elucidated, but it is speculated that the activation might occur as a result of $A \beta 42$ toxicity and unknown death pathway, not the cause for the death. Although YVAD-FMK, z-IETD-FMK, and z-LEHD-FMK showed a significant toxicity (Fig. 2B, C and D), which made it difficult to probe the effect of the relevant caspases, the pan-caspase inhibitor, z-VAD-FMK, was ineffective in preventing the cell death (Fig. 2E). This data further support that the caspase inhibitors were unable to prevent $A \beta$-induced cell death which may proceed independently of caspase activation.

\section{Conclusion}

Although it is generally accepted that $A \beta$ induces apoptotic neuronal death, the particular pathways of the apoptotic cell death programme that are involved in $A \beta$ toxicity remains unclear. Caspases have been widely implicated as essential mediators of many types of neuronal apoptosis, including $A \beta$-mediated cell death ${ }^{[5-7]}$. Caspase- 3 is the enzyme most strongly implicated in the pathogenesis of $A \beta$-induced apoptosis. Activation of caspase- 3 occurs in multiple cell types after $A \beta$ application as demonstrated by increased cleavage of fluorogenic substrates, increased levels of activated subunits by immunoblot analysis ${ }^{[17,18]}$. Moreover, protection against $A \beta$ induced apoptotic cell death with a caspase3 inhibitor has been reported ${ }^{[17]}$. In contrast, the studies also indicated that the selective inhibitor for caspase- 3 is ineffective against $A \beta$ mediated cell death ${ }^{[18,19]}$.

In the present study, we invariably observed a significant activation of caspase-3 (Fig. 1A). Caspase-3 can be activated by initiator caspases such as caspase- 8 and -9. Consistently, the activation of those initiator caspases was observed as shown in Fig. 1A and B. However, its implication in the apoptotic pathway is somewhat obscure, because the two initiator caspases mediate the different pathway ${ }^{[20]}$. Thus, it is difficult to point to one clear mechanism for the activation of caspase-3. One speculation is that different structures of $\mathrm{A} \beta$ can induce a different apoptotic pathway ${ }^{[21]}$, which may explain the result. On the other hand, caspase-1 activation was not detected (Fig. 1A), suggesting the caspase-inducing pyroptosis might not be involved.

Although caspase- 3 and its activators such as caspase- 8 and -9 were activated in a significant level, the inhibitors for each caspase and the pan-caspase inhibitor failed to prevent the cell death (Fig. 2A-E). The activation of the caspases, therefore, may not cause the death, but might function for other purpose. Apoptosis is a type of cell death to minimize release of cell contents which might raise the immune response. In the contexts, it might be suggested that the activation of caspase in $\mathrm{A} \beta$-treated cell is necessary to remove cell contents rather than cell death to reduce unwanted physiological response. The current study will be the opening to further investigate the actual role of caspases activated by $A \beta$ treatment as well as the pathways following to kill the cells by the peptide.

Abbreviations: $\mathrm{A} \beta$, amyloid beta; MTT, 3-(4,5dimethylthiazol-2-yl)-2, 5 diphenyl tetrazolium bromide; DTT, dithiothreitol; SDS-PAGE, Sodium dodecyl sulfate - Poly acrylamide gel electrophoresis; HRP, horse radish peroxidase; $Z$, benzyloxycarbonyl; FMK, fluoromethyl ketone; Ac, acetyl; AMC, aminomethylcoumarin; PVDF, polyvinylidene fluoride.

\section{References}

[1] J. Hardy and D. J. Selkoe, "The amyloid hypothesis of Alzheimer's disease: progress and problems on the road to therapeutics", Science, Vol. 297, pp. 353-356, 2002.

[2] D. T. Loo, A. Copani, C. J. Pike, E. R. Whittemore, A. J. Walencewicz, and C. W. Cotman, "Apoptosis is induced by $\beta$-amyloid in cultured central nervous system neurons", Proc. Natl. Acad. Sci. USA, Vol. 90, pp. 7951-7955, 1993.

[3] A. Copani, V. Bruno, G. Battaglia, G. Leanza, R. Pellitteri, A. Russo, S. Stanzani, and F. Nicoletti, "Activation of metabotropic glutamate receptors protects cultured neurons against apoptosis induced by $\beta$-amyloid peptide", Mol. Pharmacol., Vol. 47, pp. 890-897, 1995.

[4] K. J. Ivins, E. T. N. Bui, and C. W. Cotman, " $\beta-$ Amyloid induces local neurite degeneration in cultured hippocampal neurons: evidence for neuritic apoptosis", Neurobiol. Dis., Vol. 5, pp. 365-378, 1998.

[5] J. Yuan and H. R. Horvitz, "A first insight into the 
molecular mechanisms of apoptosis", Cell, Vol. 116, pp. 53-56, 2004.

[6] E. Masliah, M. Mallory, M. Alford, S. Tanaka, and L. A. Hansen, "Caspase dependent DNA fragmentation might be associated with excitotoxicity in Alzheimer disease", J. Neuropathol. Exp. Neurol., Vol. 57, pp. 1041-1052, 1998.

[7] J. W. Allen, B. A. Eldadah, X. Huang, S. M. Knoblach, and A. I. Faden, "Multiple caspases are involved in $\beta$-amyloid induced neuronal apoptosis", J. Neurosci. Res., Vol. 65, pp. 45-53, 2001.

[8] C. Stadelmann, W. Bruck, C. Bancher, K. Jellinger, and H. Lassmann, "Alzheimer disease: DNA fragmentation indicates increased neuronal vulnerability, but not apoptosis", J. Neuropathol. Exp. Neurol., Vol. 57, pp. 456-464, 1998.

[9] J. Xiang, D. T. Chao, and S. J. Korsmeyer, "Baxinduced cell death may not require interleukin $1 \beta$ converting enzyme-like proteases", Proc. Natl. Acad. Sci. USA, Vol. 93, pp. 14559-14563, 1996.

[10] M. Deshmukh, J. Vasilakos, T. L. Deckwerth, P. A. Lampe, B. D. Shivers, and E. M. Johnson, Jr, "Genetic and metabolic status of NGF-deprived sympathetic neurons saved by an inhibitor of ICE family proteases", J. Cell Biol., Vol. 135, pp. 13411354, 1996.

[11] M. D. Johnson, H. Xiang, S. London, Y. Kinoshita, M. Knudson, M. Mayberg, S. J. Korsmeyer, and R. S. Morrison, "Evidence for involvement of Bax and p53, but not caspases, in radiation-induced cell death of cultured postnatal hippocampal neurons", J. Neurosci. Res., Vol. 54, pp. 721-733, 1998.

[12] L. Stefanis, D. S. Park, W. J. Friedman, and L. A. Greene, "Caspase-dependent and -independent death of camptothecin-treated embryonic cortical neurons", J. Neurosci., Vol. 19, pp. 6235-6247, 1999.

[13] L. A. Selznick, T. S. Zheng, R. A. Flavell, and P. Rakie, "Amyloid beta-induced neuronal death is bax-dependent but caspase independent", J.
Neuropathol. Exp. Neurol., Vol. 59, pp. 271-279, 2000.

[14] M. Shanawaz, A. Thapa, and I. S. Park, "Stable activity of a deubiquitylating enzyme (Usp2-cc) in the presence of high concentrations of urea and its application to purify aggregation-prone peptides", Biochem. Biophys. Res. Commun., Vol. 359, pp. 801-805, 2007.

[15] J. A. Watt, C. J. Pike, A. J. Walencewicz-Wasserman, and C. W. Cotman, "Ultrastructural analysis of $\beta$-amyloid induced apoptosis in cultured hippocampal neurons", Brain Res., Vol. 661, pp. 147-156, 1994.

[16] Y. Shi, "Mechanisms of caspase activation and inhibition during apoptosis", Mol. Cell, Vol. 9, pp. 459470, 2002.

[17] J. Harada and M. Sugimoto, "Activation of caspase3 in $\beta$-amyloid induced apoptosis of cultured rat cortical neurons", Brain Res., Vol. 842, pp. 311-323, 1999.

[18] C. M. Troy, S. A. Rabacchi, W. J. Friedman, T. F. Frappier, K. Brown, and M.L. Shelanski, "Caspase2 mediates neuronal cell death induced by $\beta$ amyloid", J. Neurosci., Vol. 20, pp. 1386-1392, 2000.

[19] J. Sáez-Valero, N. Angeretti, and G. Forloni, "Caspase-3 activation by beta-amyloid and prion protein peptides is independent from their neurotoxic effect", Neurosci. Lett., Vol. 293, pp. 207-210, 2000.

[20] I. Budihardjo, H. Oliver, M. Lutter, X. Luo, and X. Wang, "Biochemical pathways of caspase activation during apoptosis. Annual Review of Cell and Developmental", Biology, Vol. 15, pp. 269-290, 1999.

[21] P. Picone, R. Carrotta, G. Montana, M. R. Nobile, P. L. S. Biagio, and M. Di Carlo, "A $\beta$ oligomers and fibrillar aggregates induce different apoptotic pathways in LAN5 neuroblastoma cell cultures", Biophys. J., Vol. 96, pp. 4200-4211, 2008. 